\title{
The Death of Guguritan Sunda
}

\author{
D Hendrayana \\ \{dian.hendrayana@upi.edu \\ Universitas Pendidikan Indonesia, Bandung, Indonesia
}

\begin{abstract}
The purpose of this study was to see how the development of the Sundanese poetry in the past two decades. Guguritan in the Sundanese literature includes the types of old poetry beside mantra, sisindiran, kawih, pupujian, and puisi pantun. However, compared to other old (Sundanese) poetry material, the guguritan is still written and read by the Sundanese. The method used in this study is the analytical description method, in which the guguritan collected in magazines or newspapers is explored to see the extent to which the guguritan is still read by the people. The results obtained indicate that the guguritan in the past two decades is not much written by the author. Therefore, towards the guguritan, there needs to be a very integrated handling effort so that the material of the guguritan can be sustained and developed in the treasures of Sundanese literature.
\end{abstract}

Keywords: Guguritan, Pupuh, Cianjuran

\section{INTRODUCTION}

Although not as many as the decade of the 90s and the first decade of the XXI century, writing in guguritan treasures literature in the last ten years is still written and read. Especially in the 90s, guguritan presence in the mass media enough to be attented. In the early '90s has published the first book of guguritan , Jamparing Hariring $(\mathrm{JH})$ by Dedy Windyagiri. While at the end of the decade of 90s, the book of guguritan Jaladri Tingtrim (JT) by Dyah Padmini has published. The presence of these two books gave an indication that guguritan is still written and read. Moreover, the JT was awarded Rancage (literary award) as the best literature which published in 1999. Then, at the beginning of the XXI century, published the book of guguritan Riring-riring Ciawaking (RC) by Wahyu Wibisana and Lagu Liwung Urang Bandung (LLUB) by Apung SW.

The presence of poetry guguritan until the '60s, very closely related to the world of art Cianjuran [1]. In the cianjuran, there is the art of song material that uses poetry guguritan , namely tembang Rarancagan and tembang Dedegungan.

\section{METHOD}

Guguritan in Sundanese literature terms was different with guguritan in Javanese literature terms. Guguritan in Sundanese literature as a means of poetry which ussed rules pupuh, while guguritan in Javanese literature is no other rhyme (free verse poem modern) in the Sundanese 
literature [2]. Pupuh is a rule made in metrical poetry dangding (consisting of guguritan and wawacan) [3].

Pupuh does not belong Sundanese, but the influence of Javanese culture. The effect occurs around the 18th century in the form of wawacan [4]. The pupuh by experts mentioned there are 17 stanzas: Kinanti, Sinom, Asmarandana, Dangdanggula, Mijil, Pangkur, Durma, Gurisa, Gambuh, Ladrang, Lambang, Maskumambang, Balakbak, Magatru, Pucung, Wirangrong, and Jurudemung.

Cianjuran is the art of sound typical users from Cianjur. This art was originally formed from the invisible poem is repackaged by the regent of Cianjur, RAA Kusumaningrat, around midnineteenth century [1]. In the development of this art has six (6) of the technique and style of chant, which Papantunan, Jejemplangan, Rarancagan, Dedegungan, Kakawen, and Dedegungan. Especially in the Rarancagan, since the post-independence period, the art of music to meet a lot of progress, especially since very direct contact with the material guguritan, who at that time was growing rapidly [5].

\section{RESULTS AND DISCUSSION}

In the period of 1990 to 2000, the guguritan was often found in the mass media, especially in Mangle and Galura newspapers. Moreover, Mangle magazine, in almost every publication, always contains the guguritan [6].

There are three names that are quite prominent in terms of writing in the 1990s, namely Dedy Windyagiri, Dyah Padmini, and Wahyu Wibisana [7]. The scourging of the three poets is considered to be a deceit that has its own character that is able to color and provide inspiration for Sundanese literature and Sundanese society in general, especially after the 90s.

Judging from its position, the fall of the three poets became monumental works, namely 1) The guguritan of Dedy collected in JH book was the first collection of knockoffs in the treasures of Sundanese Literature, and had made trending topics after its publication in 1992 , some of the works by Dedy Windyagiri were awarded the LBSS literary prize (Sundanese Literature Institute); 2) The guguritan of Dyah Padmini's work published in 1999 was awarded the Literature Rancage Prize as the best literary book published in 1999; 3) The guguritan of Wahyu Wibisana became a scourge that was often sung to the art of cianjuran [8].

\subsection{Wahyu Wibisana}

This writer was born in Cisayong Tasikmalaya, 1939. Writing in the form of prose, poetry, and drama. His short stories in Sundanese received much praise for their high literary value; just call Aki Warung, Kawung Ratu, and Dehem short stories to name a few. His well-known drama's scripts include the Tukang Asahan and Tonggeret Banen. While the musical drama manuscripts include Si Kabayan, Ciung Wanara, Mundinglaya di Kusumah, and Lutung Kasarung. As for writing his poems, Wahyu included poets who were adept at writing sajak (free poetry, modern poetry) and also scorn [9].

In its golden age, the revelation of Wahyu Wibisana was widely used in cianjuran performances and ritual ceremonies from the Mayang Binekas Group, a large-scale art studio in the city of Bandung. Revelation manuscripts that use a lot of tyrannical material are often a trend and are remembered in the minds of the musicians, such as the Asmarandana Mahoni di Cipaganti, Sinom Nonggoh jalan ka Kuningan. or Dangdanggla Duh pameunteu teuteupeun awaking. 
Many of the works of Wahyu Wibisana are then sung in the art of cianjuran. One of the popular pieces of Wahyu Wibisana was written using pupuh Asmarandana, and was sung in the song Eros. See the text:

\author{
Mahoni di Cipaganti \\ tanjakan jalan ka Lémbang \\ ngasona di Gegerkalong \\ jauh kénéh ka Burangrang \\ ari rét ka Manglayang \\ aya gupay ti nu jauh \\ mega sutra lir salempay
}

\author{
Mahoni Tree along (road) Cipaganti \\ the way to Lembang \\ take a break at Gegerkalong \\ still far to Burangrang \\ to turn towards Mount Manglayang \\ there are waving hands, from afar \\ clouds like handkerchiefs
}

While guguritan written in the stanza Sinom is well-known guguritan stanza Sinom frequently sung song in doubt, namely Mangu-mangu:

\author{
Sareupna lebah Labuan \\ pamayang muru basisir \\ layarna sabelegbegan \\ hideung dina latar kuning \\ layung keur meujeuhna jadi \\ pur ngempur luhureun laut \\ dikarawang ku kalangkang \\ poék ngahaeub ka peuting \\ geus reupreupan kalapa antay-antayan
}

\author{
Twilight in Labuan \\ fishermen pull over to the beach \\ the screen forms a shadow \\ blackened in the orange sky \\ and crimson flared \\ burning above the sea \\ shielded shadow \\ dark before night \\ the coconut trees are lined up waving
}

Or guguritan stanza Sinom commonly sung in the song Téjamantri:

$\begin{array}{ll}\text { Koléang heulang ngalayang } & \text { eagle hovers } \\ \text { luhur dina tangkal kai } & \text { fly in the tree } \\ \text { siga anu mikamelang } & \text { like being homesick } \\ \text { ngalanglang bari mépéling } & \text { is it being reminded } \\ \text { geus meujeuhna anaking } & \text { never mind my child } \\ \text { buru-buru geura wangsul } & \text { hurry home } \\ \text { wangsul ka nagarana } & \text { go back to your hometown } \\ \text { geura ngahenang-ngahening } & \text { and do it } \\ \text { beurat bunghar jembarna salalawasna } & \text { so you succeed there }\end{array}$

For cianjuran art, Wahyu much donated guguritan poetry, especially in the Rarancagan [5]. Guguritan in writing, Wahyu already familiar with the background and history of natural Kasundaan; of all things related to Prabu Siliwangi and of all things related to the Pajajaran. Siliwangi was handsome, mighty, wise; Pajajaran was glorious, magnificent, and grand. That is why Wahyu's guguritan more effectively dashing and masculine, as seen in guguritan (Dangdanggula) below:

Siliwangi nu ngancik di mendi

Pajajaran nu aya di mana

koréléng horéng na hate

dina kentrung jajantung
Siliwangi who lives in where

Pajajaran who lives where

it was in the heart

right inside the heart beat 
usik-usik na sanubari

lebah Sipatahunan

aing manjing ingsun

peupeuntasan keukeumbingan

jol ka tegal Si Awat-awat kiwari

reujeung Pamanahrasa pulsating in the heart

the soul Sipatahunan

inside of me

where the complacency is

coming in now

with Pamanahrasa

\subsection{Dedy Windyagiri}

This writer was born in Bandung in 1941. Apart from being known as an eloquent scribbler, Dedy is also known as a good short story writer. Similarly, with other writings in the form of poems. Several times got LBSS literary prizes for his deceased work.

In contrast to Wahyu Wibisana, Dedy's habit of writing guguritan is more seductive and feminine. The deception of Dedy's works seemed to be able to represent the nature and humiliation (conscience, ideology) of women. Emotions that are often felt and delivered by women, as if expressed articulatively through Dedy's fall. As in the death using Sinom poetry below:

Na naon atuh margina

engkang téh dugi ka lali

da menggah diri abdi mah

asa teu kirang gumusti

gumati lahir batin

teu luntur pengkuh sumujud

satia mikatresna

wekasan diapilain

luas nolas ka nu teu tutas miwelas.
What are my sins and mistakes

so you leave me

know it

I was always faithful

as sincere as my heart and soul

and never turned away

faithful love you

but why do you hurt me

You hurt sincerity, my love

Wahyu and Dedy, both have the same intellectual who attended high art music. Both understand too, how to write guguritan Dangdanggula, Sinom, Asmarandana, Kinanti nice and proportional to the songs sung in the music. Guguritan written so that both the poets who have fatigue beautiful, and force the rhythm that tunable, jeweled headband with style and alliteration stunning.

Even so feminine with guguritan written Dedy. Guguritan Dedy composed by Mang Engkos to track the subject in the mood Rarancagan barreled sorog, 'Pegat Duriat' (broken love).

In 1996, Enip Sukanda enters guguritan Dedy Windyagiri material as songs (lyrics) song competitions cianjuran Damas XIV. Previously, the lyrics of the song using the music of the songs Idi Rosadi, H. Hanafi, Mr. Abubakar, or footage of Guguritan Laut Kidul, as well as excerpts from wawacan. Even for a single music album, Enip Sukanda also choose guguritan owned Dedy; and become a music album 'Kasmaran Kasamaran' in 1997 by the singer Hendrawati and Herry Suheryanto.

As Wahyu custom work, guguritan s Dedy's was used as the lyrics in the cianjuran. For example, one poem guguritan work Dedy Windyagiri is:

$\begin{array}{ll}\text { Pamungkas abdi talatah } & \text { this is my last message } \\ \text { upami dugi ka pati } & \text { if I die } \\ \text { rurub ku karémbong téa } & \text { cover me with a shawl } \\ \text { nu tara tebih ti abdi } & \text { the shawl I used to hug } \\ \text { nu cipruk ku citangis } & \text { wet with tears }\end{array}$




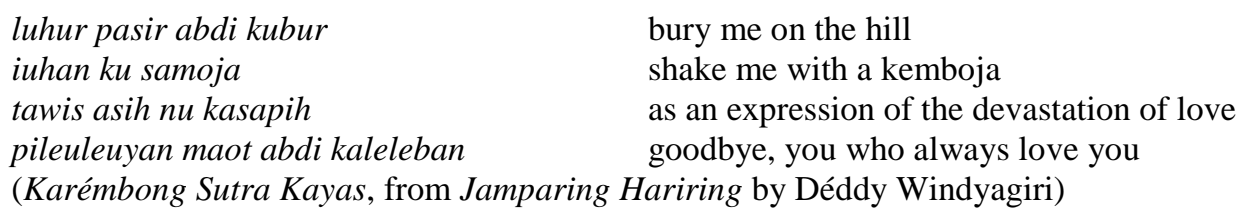

\subsection{Dyah Padmini}

This author who is also proficient in writing prose (short story) and sharp in devoting ideas to essays. His works, including guguritan, are often published in Mangle magazine.

She was born in Sukabumi in 1941. In the 1980s until the early 1990s he spent time traveling in Italy and France. It was his association and experience while abroad, he spilled through the work of fiction and non-fiction, including in the scourge. Especially in the decade of the 90s, a lot of guguritan appeared and quite struck the Sundanese people, because the contents seemed to break down the previous habits of the guguritan character who were accustomed to offering lively or melancholic content or love stories, such as the death of Dedy Windyagiri and other poets as often read in the fallout of the designation of cianjuran art.

See one of the verses of the poem of the knockout in Pupuh Dangdanggula:

\author{
Ngambah dunya diri mingkin leutik \\ nyawang alam tataran Afrika \\ ngarandeg palebah léngkob \\ panon teu wasa ngukur \\ pigurana sapipir langit \\ lewang raheut tengahna \\ dina hiji waktu \\ manéhna ngewag gudawang \\ ngan hanjakal kuring moal jadi saksi \\ Afrika dibeulah dua
}

The smaller I am in the sky when I saw African land stumbling in the valley's expanse my eyes unseen confined to the horizon like a wound in the middle at one time he has indeed been injured but I will not testify Africa has splitted in two

Or the couplet guguritan Simpy below:

Ka rundayan teureuh Siliwangi anu nyangking nya si kujang runcang geura ponténgkeun srangéngé bur lelemah sing mancur dina lebah tutunggul nagri bagal bumi Pakuan geus mangsa manggung nanjeurkeun kahayang alam gunung urug tetengger kula deuk nitis ngerabkeun hideung bodas

\author{
For Siliwangi's children and grandchildren \\ inherited cleaver kujang \\ hold the sun \\ turn on your land of birth \\ right in the city center \\ the heart of Pakuan city \\ the time has come \\ become state acting \\ if the mountain collapsed \\ that's me, fly the banner resurrection
}

Diction and idioms that are often chosen by Dyah in writing guguritan are always protected from the selection of a seductive, soft, lyrical diction such as diction which is usually chosen by the scribe author for the purposes of traditional arts. The tone and atmosphere offered by Dyah is just like explosiveness and there is an atmosphere and bold characters like those of men. In Dyah's work, there is no impression of melancholy, or romantic tones. Dyah seemed to want to 
voice his heart out loud, full of anger, and fighting, fighting, and masculine. Even the 'masculinity' Dyah in deceit like surpassing the supernatural spirit of Wahyu Wibisana.

The style writing of guguritan shown by the three poets in the 1990 s seemed to be a development in the style of the poetry from the previous period [5]. Pilemburan (hometown) themes, landscapes of prosperous fertile lands they have left behind. And this year's range has become the most recent creation theme for the fallacy. The three names of these poets may be said to be the peak of the writings of the poet, which was then marked by the publication of a book that contained their respective works.

\subsection{The Death of Guguritan Sunda}

Along with the passage of time, the poets met old times, times which reduced the productivity of work. Dedy Windyagiri and Wahyu Wibisana later died in 2014. While Dyah Padimini was destroyed by the earth, his works no longer appeared. Its productivity seemed to stop when it entered the 2000s. Dyah, who in the 90s lived in Bandung, has resettled in Sukabumi.

The sinking of the works of the three writers of the scythe was not replaced much by poets afterwards. The poet's third proficiency in writing guguritan with a myriad of insights about the subject matter, not much 'dripping' in the next poets. The next poets poured out their hearts in sajak (free poetry, modern poetry). The fact, the true guguritan writers are poets who are skilled at writing texts and are skilled in menembang (sung). And that ability is rarely possessed by most poets. So this is one of the declining writings in Sundanese literature.

Even so, because there were no poets who struggled in the affairs of the guguritan, the mass media had difficulty loading poetry in the form of guguritan. Some names of new poets such as Etti RS, HD Bastaman, Kania, until Tyas Nastiti Puri did not have the loyalty that Dedy, Wahyu, and Dyah had in writing down the guguritan [10]. So, in the past five years, poetry works in the form of guguritan are very rare in the mass media [11]. Moreover, the mass media that faithfully carried out the scornful works until now are only two media, namely Manglé magazine and (sometimes) the Sunda Midang magazine.

\section{CONCLUSIONS}

The decline in productivity in the writing of the poetry is motivated by a pattern that is deeply patterned by the rules of pupuh. Poets seem to avoid the rule of pupuh in pouring out their heart; poets want to feel the freedom that is as free in indulging and overflowing their hearts.

Writing the guguritan demands proficiency in choosing diction in the loopholes of the rules of pupuh which are felt to be shackled. In addition, the writing of the dropout poem also requires knowledge to menembang (to song guguritan ) which is quite capable. This is of course very related to the need for freshing (beheading, breathing, enjabement) when singing songs. This ability is not shared by most poets.

After the death of Dedy Windyagiri and Wahyu Wibisana, the writing of guguritan is like going to the twilight and as if to meet his death. There are not many poets who choose concentration in the writing of guguritan . Poets are more involved in sajak writing, and like avoiding guguritan that is not 'giving' freedom in pouring out his heart. With the decline in productivity, the creation of a scapegoat clearly impacts the productivity of poetic poetry loading in the mass media. This is the twilight of the writing the guguritan . 


\section{REFERENCES}

[1] E. Sukanda, Riwayat Pembentukan dan Perkembangan Cianjuran. Yayasan Pancaniti kerja sama Dinas Pariwisata dan Kebudayaan Jabar, 2016.

[2] A. Rosidi, Ngalanglang Kasusastraan Sunda. Jakarta: Pustaka Jaya, 1983.

[3] Satjadibrata, Rasiah Tembang Sunda. Bandung: Ganaco, 1953.

[4] A. Rosidi, Wawacan. Bandung: Kiblat Buku Utama, 2011.

[5] D. Hendrayana, Dina Kawih Aya Tembang. Bandung: CV Geger Sunten.

[6] D. Hendrayana, "Memelihara Riak Sastra Sunda," Jurnal Paramasastra, vol. 4, no. 2, 2018.

[7] D. Hendrayana, "Guguritan Sunda dalam Tiga Gaya Penyair," Jentera, vol. 7, no. 1, 2018.

[8] A. S. Wiratmaja, Kuring jeung Tembang Sunda. Bandung: Citra Mustika, 1996.

[9] D. Hendrayana, "Sundanese Literature The Last Three Decades," 2019.

[10] D. Hendrayana, "Puisi Sunda Seperempat Abad Terakhir," in Prossiding Ikadbudi Makassar 2017, 2017.

[11] N. Kurniasih, E. Rizal, Y. Winoto, N. Kurniawati, A. Sudirman, A. Hasibuan, A. Daengs GS, and K. Saddhono. "Online Media as a Movie Reference." In Journal of Physics: Conference Series, vol. 1114 no. 1, p. 012087. IOP Publishing, 2018. 